\title{
The detection of Helicobacter pylori cag pathogenicity islands (PAIs) and expression of matrix metalloproteinase-7 (MMP-7) in gastric epithelial dysplasia and intramucosal cancer
} \author{
Min Kyoung LeE ${ }^{3}$, and Yun Kyung Lee ${ }^{4}$ \\ ${ }^{1}$ Department of Internal Medicine, College of Medicine, the Catholic University of Korea, Seoul, Korea \\ ${ }^{2}$ Department of Pathology, College of Medicine, the Catholic University of Korea, Seoul, Korea \\ ${ }^{3}$ The Research Institute of St. Vincent Hospital, the Catholic University of Korea, Suwon, Korea \\ ${ }^{4}$ Department of Pathology, Samsung Medical Center of Korea, Seoul, Korea
}

Woo Chul Chung ${ }^{1}$, Sung Hoon Jung ${ }^{1}, \mathrm{Kang}$ Moon Lee ${ }^{1}$, Chang Nyol Paik ${ }^{1}$, Jea Wuk Kawk ${ }^{1}$, Ji Han Jung ${ }^{2}$,

\begin{abstract}
Background. The cag pathogenicity island (PAI), a Helicobacter pylori virulence factor, is associated with the pathogenesis of gastric cancer. Matrix metalloproteinase-7(MMP-7) is upregulated in the epithelial cells of gastric cancer. To date, there is limited information available on the role of $\mathrm{cag}$ PAI and MMP-7 in precursor lesions. In this study, we aimed to identify virulent $H$. pylori strains and the expression of MMP-7 in samples of gastric epithelial dysplasia and intramucosal cancer.

Methods. One hundred and twelve tissues excised by endoscopic mucosal resection, 76 specimens with gastric epithelial dysplasia and 36 with intramucosal cancer, were examined. All tissue samples were paired with surrounding normal epithelial tissue samples. We performed polymerase chain reaction for $\operatorname{cag} A$ and $\operatorname{cag} L$ in neoplasia and paired normal specimens, and assessed the matrix metalloproteinase (MMP)-7 expression by immunohistochemical staining.

Results. There was a significant difference in the frequencies of $\operatorname{cag} \mathrm{A}$ or $\operatorname{cag} \mathrm{L}$ between specimens with gastric dysplasia and those with intramucosal cancer. We confirmed greater expression of MMP-7 immunoreactivity in intramucosal cancers infected with a virulent $H$. pylori strain.

Conclusion. Our results suggest that infection with a virulent $H$. pylori strain was associated with early-stage gastric cancer and that carcinogenesis was associated with cag PAI-dependent MMP-7 upregulation.
\end{abstract}

Key words Helicobacter pylori - Virulence factor · Matrix metalloproteinase

Offprint requests to: K.-M. Lee

Department of Internal Medicine, St. Vincent Hospital, the Catholic University of Korea, 93-6 Ji-dong, Paldal-gu, Suwon, Gyunggi-do 442-723, Korea

Received: October 22, 2009 / Accepted: March 10, 2010

\section{Introduction}

More than $50 \%$ of the world's population harbor Helicobacter pylori in the upper gastrointestinal tract. However, more than $80 \%$ of individuals infected with this bacterium are asymptomatic; only a fraction of infected individuals develop clinical disease $[1,2]$. The clinical response to infection is likely determined by the virulence of the infecting strain and the host genetic predisposition, as well as environmental factors. Virulent $H$. pylori strains having cytotoxin-associated gene pathogenicity islands (cag PAI) have been associated with a more aggressive clinical course due to the increased inflammatory response of the gastric mucosa [3-6]. H. pylori cagA, a type of cag PAI, is associated with severe gastritis and gastric carcinoma. Patients infected with $H$. pylori who have cagA antibodies are more likely to develop gastric cancer compared to uninfected patients or $H$. pylori-infected patients without cagA antibodies [7-9]. In a recent study, H. pylori cagL was identified as a specialized adhesin protein that targets the pilus surface, where it binds to and activates the integrin $\alpha 5 \beta 1$ receptor on the gastric epithelial surface, which facilitates the injection of cagA into host cells and activates host tyrosine kinases [10]. However, there is limited information currently available on the role of cag PAI in vivo, especially in premalignant gastric lesions, and the mechanism concerning how it contributes to gastric carcinogenesis is still obscure.

Matrix metalloproteinases (MMPs) are a family of diverse zinc-dependent proteolytic enzymes that are important in the maintenance and remodeling of the cell-cell matrix and the extracellular matrix. MMP-7 is a member of the MMP family and is upregulated in the epithelial cells of gastric cancer; it can promote cancer invasion by the proteolytic cleavage of extracellular matrix substrates [11-13]. Previous studies have reported that virulent $H$. pylori strains resulted in the selective 
induction of MMP-7 in vitro and in the gastric mucosa $[14,15]$. The goal of the present study was to identify virulent $H$. pylori strains and the expression of MMP-7 in samples of gastric epithelial dysplasia and intramucosal cancer, obtained by endoscopic mucosal resection, in order to elucidate the effects of virulent $H$. pylori strains during the early stages of malignant transformation.

\section{Methods}

\section{Ethical statement}

Human samples were used according to the guidelines of the Ethics Committee of the Catholic University of Korea.

\section{Materials}

All tissues were therapeutically excised by endoscopic mucosal resection. The diagnosis of the tissue samples, according to the revised Vienna classification [16], was confirmed by two different histopathologists; when the reviewers disagreed, the tissue sample was excluded from the study. We did not include samples with noninvasive carcinoma in situ [CIS], category 4.2) or samples suspicious of invasive carcinoma (category 4.3). A total of 149 tissue samples were analyzed; 37 tissue samples were excluded because of disagreement on the diagnosis or because of inappropriate tissue preparation. The remaining 112 samples had gastric epithelial dysplasia and intramucosal cancer and were included in the analysis.

Seventy-six samples with gastric dysplasia and 36 intramucosal cancer tissue samples were paired with adjacent normal mucosal tissues. All normal tissues had grossly intact mucosa and were at least $1 \mathrm{~cm}$ from the mucosal lesion; they were taken as a gastric biopsy just after the endoscopic mucosal resection. Microscopic examination showed no evidence of malignant cells. Grading of gastritis (infiltration by chronic inflammatory cells and polymorphonuclear neutrophil [PMN] cells) was performed using the updated Sydney system [17], a scoring system with scores ranging from $0=$ none to $3=$ severe. The presence of intestinal metaplasia was also observed. Morphometric changes of gastric mucosal atrophy (closed or open type) were decided by endoscopic findings. The baseline characteristics of this study population and differences between the groups are summarized in Table 1.

\section{H. pylori status}

Each patient was classified as $H$. pylori-positive or -negative according to the histological results. In the present study, the resection specimen and gastric biopsy of surrounding mucosa were stained with hematoxylin and eosin and silver stains. To assess $H$. pylori status accurately, two biopsies were taken, from both antrum and corpus, 4 weeks after the endoscopic resection. We evaluated H. pylori status with the CLO test or by histological examination.

Table 1. The clinical features of gastric epithelial neoplasias

\begin{tabular}{|c|c|c|c|}
\hline & Gastric dysplasia & Intramucosal cancer & $P$ value \\
\hline \multicolumn{4}{|l|}{ Sex } \\
\hline Male & 40 & 25 & \multirow[t]{2}{*}{0.09} \\
\hline Female & 36 & 11 & \\
\hline Age (years) & $63.39 \pm 8.37$ & $63.81 \pm 9.02$ & 0.81 \\
\hline \multicolumn{4}{|l|}{ Site } \\
\hline Antrum & 58 & 30 & \multirow[t]{4}{*}{0.40} \\
\hline Body & 18 & 6 & \\
\hline Histological classification & Low grade 46 & Well-differentiated & \\
\hline & High grade 30 & Moderate & \\
\hline \multicolumn{4}{|l|}{ Surrounding mucosa } \\
\hline \multicolumn{4}{|l|}{ Grade of gastritis } \\
\hline Chronic inflammatory cell & $1.37 \pm 0.49$ & $1.56 \pm 0.61$ & 0.08 \\
\hline PMN infiltration & $0.96 \pm 0.62$ & $1.39 \pm 0.64$ & 0.001 \\
\hline \multicolumn{4}{|l|}{ Intestinal metaplasia } \\
\hline Positive & 74 & 35 & \multirow[t]{2}{*}{0.96} \\
\hline Negative & 2 & 1 & \\
\hline \multicolumn{4}{|l|}{ Atrophy } \\
\hline Closed type & 19 & 11 & \multirow[t]{2}{*}{0.54} \\
\hline Open & 57 & 25 & \\
\hline
\end{tabular}

Grading of gastritis (infiltration by chronic inflammatory cells and polymorphonuclear neutrophil (PMN) cells) was performed using the updated Sydney system 


\section{DNA extraction}

Two $10-\mu m$-thick tissue sections, from cancer samples and normal tissues, were placed on glass slides. Then xylene $(1 \mathrm{ml})$ was added to the tissue sections, and they were incubated for $10 \mathrm{~min}$; this process was repeated three times. The slides were then dehydrated in graded ethanol solution (100\% ethanol; $1 \mathrm{ml}$ ) and dried without a cover glass for $10 \mathrm{~min}$; this procedure was repeated three times. The DNA was extracted from the tissues with $20 \mu \mathrm{l}$ of extraction buffer $(100 \mathrm{mmol} / \mathrm{l}$ Tris- $\mathrm{HCl}$; $2 \mathrm{mmol} / \mathrm{l}$ ethylenediamine tetraacetic acid [EDTA], $\mathrm{pH}$ $8.0 ; 400 \mu \mathrm{g} / \mathrm{ml}$ of proteinase $\mathrm{K}$ ) at $55^{\circ} \mathrm{C}$ overnight. The tubes were boiled for $7 \mathrm{~min}$ to inactivate the proteinase $\mathrm{K}$, and were cooled on ice. Then $20 \mu \mathrm{l}$ phenol:chloroform:isoamyl alcohol $(25: 24: 1)$ solution was added and the tubes were centrifuged at $12000 \mathrm{rpm}$, at $4^{\circ} \mathrm{C}$ for $5 \mathrm{~min}$. This was a de-proteinization process to extract DNA from the tissue. Ethanol ( $1 \mathrm{ml} ; 100 \%)$ was added to the supernatant by and the tube was gently inverted. It was incubated at $-20^{\circ} \mathrm{C}$ for $10 \mathrm{~min}$ and centrifuged at $12000 \mathrm{rpm}, 4^{\circ} \mathrm{C}$ for $5 \mathrm{~min}$. A DNA pellet was made by washing with ethanol $(1 \mathrm{ml}, 75 \%)$ and centrifuging at $14000 \mathrm{rpm}$ for $5 \mathrm{~min}$. The pellet was dissolved by the addition of $20 \mu \mathrm{l}$ dextrose water, and then $1 \mu \mathrm{l}$ of this extract was used for each polymerase chain reaction (PCR) amplification.

\section{$P C R$ for $\operatorname{cag} A$ and $\operatorname{cag} L$ associated with $\mathrm{H}$. pylori}

PCR analysis for cag PAI was performed to amplify the cagA and $\operatorname{cag} \mathrm{L}$ genes. The primers used for detecting the $H$. pylori-specific cagA and $c a g \mathrm{~L}$ region were $5^{\prime}$-GAT AAC AGG CAA GCT TTT GA-3' (F)/ 5'-CCG AAC GGA TCA AAA ATT CAT GG-3' (R)(GenBank accession number, AF001357) and 5'-TAT TGT CTG TTT TGA TGG CAG AAG-3' (F)/ 5'-CGG ATA TTC CGC ATT GTT GC-3'(R). The PCR reaction was set up using i-star Taq DNA polymerase (iNtRON, Seongnam, Korea). The PCR amplification protocol was as follows: $95^{\circ} \mathrm{C}$ for $5 \mathrm{~min}$, then denaturing at $94^{\circ} \mathrm{C}$ for $30 \mathrm{~s}$, annealing at $50^{\circ} \mathrm{C}$ for $30 \mathrm{~s}$, extension at $72^{\circ} \mathrm{C}$ for $1 \mathrm{~min}$ for 35 cycles, and then a final extension at $72^{\circ} \mathrm{C}$ for $10 \mathrm{~min}$. The amplified products were electrophoresed on $2 \%$ agarose gels, and then visualized with ethidium bromide (Fig. 1).

\section{Immunohistochemical staining of matrix metalloproteinase-7}

Four-micrometer-thick tissue sections from the dysplasia/cancer specimens were placed on a glass slide and stained with antibodies to MMP-7 (Abcam, Cambridge, UK). The samples were deparaffinized in xylene and rehydrated in graded ethanol. Endogenous peroxidase activity was blocked with $3 \% \mathrm{H}_{2} \mathrm{O}_{2}$ in phosphatebuffered saline. For antigen retrieval, the sections were incubated in $10 \mathrm{mM}$ of citrate buffer ( $\mathrm{pH} \mathrm{6.0),} \mathrm{using} \mathrm{a}$ microwave oven. Then the sections were incubated for $30 \mathrm{~min}$ at room temperature with anti-MMP-7 antibodies $(5 \mu \mathrm{g} / \mathrm{ml})$. Antibody detection was performed using the IMPRESS peroxidase reagent kit (Vector Laboratories, Burlingame, CA, USA) according to the manufacturer's protocol. MMP-7-positive cells were identified using a DAB peroxidase substrate kit (Vector Laboratories,).

We assessed the MMP-7 staining intensity. We were particularly interested in the localization of the immunoreactivity. The stained samples were divided into two categories: a dispersed cytoplasm pattern and nucleus/ subnucleus condensation, and the staining intensity was graded from 0 (no staining) to 3 (intense staining) (Fig. 2). If both cytoplasm and nucleus/subnucleus condensation were observed, the total score for MMP-7 expression was the staining intensity plus one point (Fig.

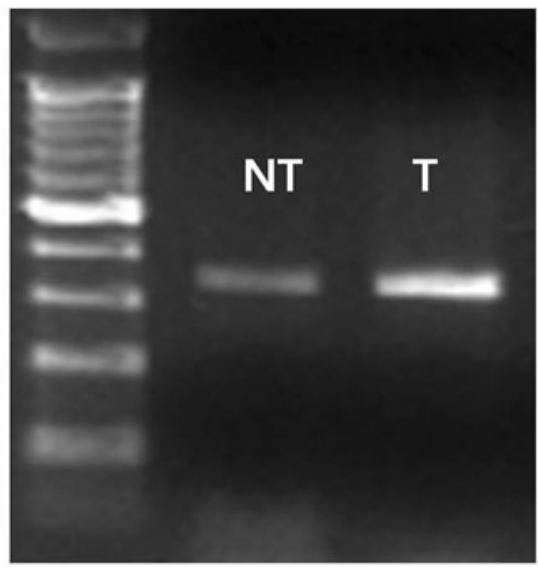

Cag A

(Location : 5'end 157-505, 349kb)

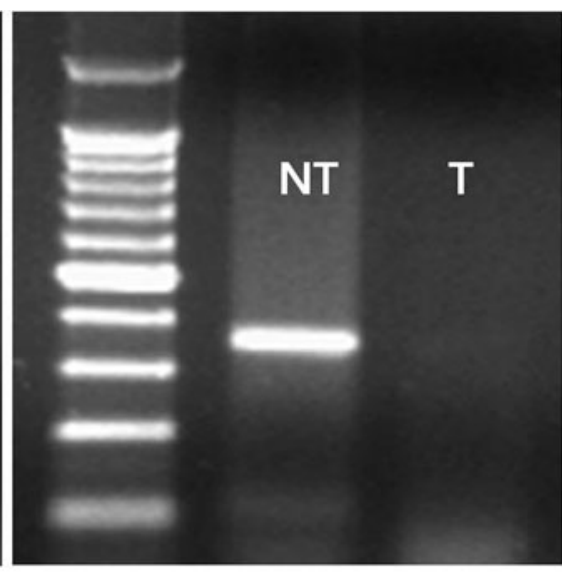

Cag L

(Location : 3'end 22941 - 23294, 354kb)
Fig. 1. Representative example of polymerase chain reaction (PCR) for cagA and cagL associated with Helicobacter pylori. $N$, Normal tissue; $T$, tumor 

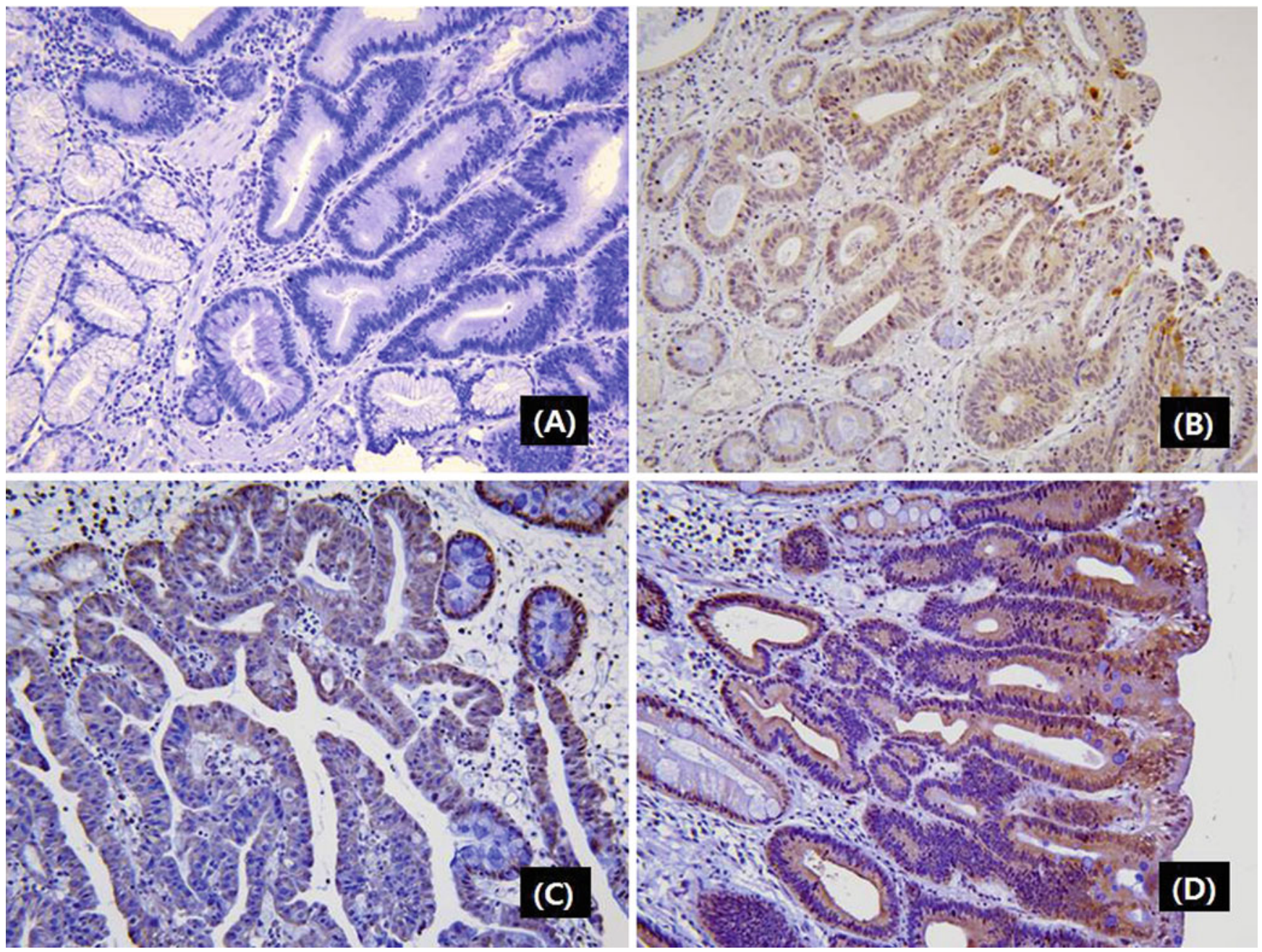

Fig. 2A-D. Immunohistochemical staining of matrix metalloproteinase-7 (MMP-7). The staining intensity was graded from 0 (A, no staining) to 3 (D, intense staining). $\mathbf{A}-\mathbf{D}, \times 200$

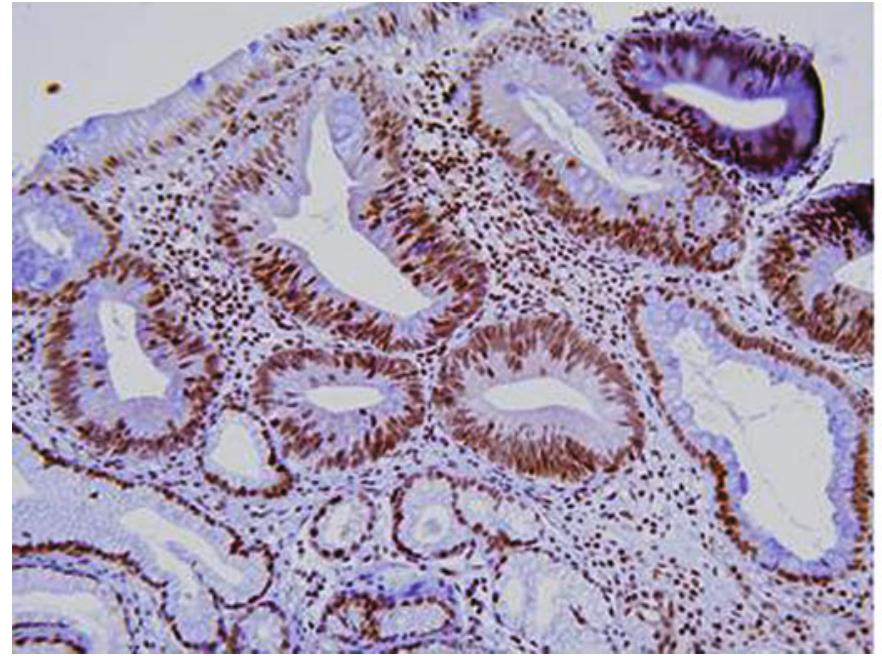

(A)

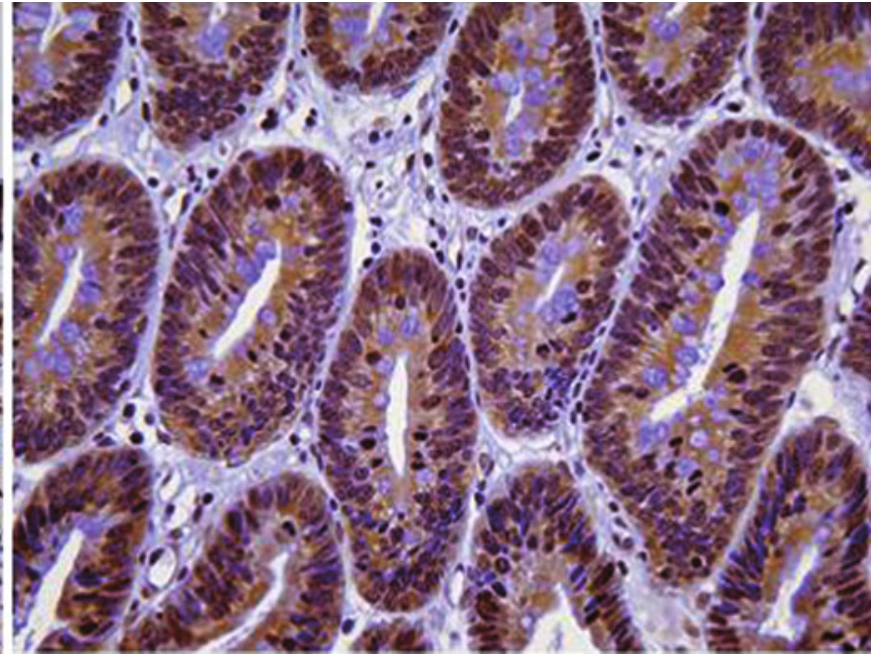

(B)

Fig. 3A,B. Immunohistochemical staining of MMP-7: expression of MMP-7 was detected in the nucleus $(\mathbf{A}, \times 200)$ or in the nucleus/cytoplasm of tumor cells $(\mathbf{B}, \times 400)$ 
3). The observers were blinded to the H. pylori status and the tissue diagnosis.

\section{Statistical analysis}

For quantitative variables, the mean and SD were calculated. For qualitative variables, the percentages and their $95 \%$ confidence intervals $(95 \%$ CIs) were calculated. We used the $\chi^{2}$ test to analyze the association between the $H$. pylori status and the prevalence of $\operatorname{cag} \mathrm{A} / \operatorname{cag} \mathrm{L}$. For comparisons of age and grade of MMP-7 expression, we used the unpaired $t$-test and one-way analysis of variance (ANOVA). The SPSS statistical package software for Windows release 12.0 (SPSS, Chicago, IL, USA) was used for all analyses. Significance was defined as $P<0.05$.

\section{Results}

A total of 149 tissue samples were analyzed; 37 tissue samples were excluded. The concordance rate between the two histopathologists was $75.2 \%$. Samples from 112 patients with gastric epithelial dysplasia and intramucosal cancer were available for the analysis. The H. pylori status was evaluated according to the histological results (silver stain or CLO test); there were 37 cases (37/76; $48.7 \%)$ of gastric dysplasia and $25(25 / 36 ; 69.4 \%)$ of intramucosal cancer that were associated with $H$. pylori infection. There were significant differences in $H$. pylori infection and cag PAI-positive rates between the gastric epithelial dysplasia specimens and the intramucosal cancers (Table 2).

When all sample tissues were categorized according to the revised Vienna classification (46 patients with low-grade dysplasia, 30 with high-grade dysplasia, and 36 with intramucosal gastric cancer), the positive rate for cagA was $52.4 \%(11 / 21)$ in category 3 cases (lowgrade dysplasia). For categories 4.1 (high-grade dysplasia) and 4.4 (intramucosal carcinoma), the rates were $60 \%(9 / 15)$ and $88.0 \%(22 / 25)$ respectively. There was an increasing tendency for intramucosal cancers to have a higher rate of positive $\operatorname{cag} \mathrm{A}$ results compared to the other samples $(P=0.02)$.

We assessed the intensity and localization of MMP-7 immunoreactivity. There was a significant difference in the grade of intensity between the gastric epithelial dysplasias and the intramucosal cancers $(2.18 \pm 0.76,2.58 \pm$ $0.77 ; P=0.01)$. When the lesions were categorized by the revised Vienna classification subgroups, the intensity of MMP-7 immunoreactivity had an increasing tendency from category 3 to category $4.4(2.15 \pm 0.63,2.23$ $\pm 0.58,2.58 \pm 0.77, P=0.03$; Fig. 4). As for the nucleus/ subnucleus condensation of MMP-7 immunoreactivity, this was less frequent in gastric dysplasia samples than in the intramucosal cancers $(15.8 \% ; 12 / 76$ vs $33.3 \%$; $12 / 36 ; P=0.03$ ).

When we compared $H$. pylori-positive gastric dysplasia with $H$. pylori-negative gastric dysplasia, MMP-7 immunoreactivity was more intense in the $H$. pyloripositive samples, but the difference was not significant $(2.19 \pm 0.77$ vs $2.08 \pm 0.70 ; P=0.51)$. In the intramucosal cancers, $H$. pylori-positive lesions showed more intense

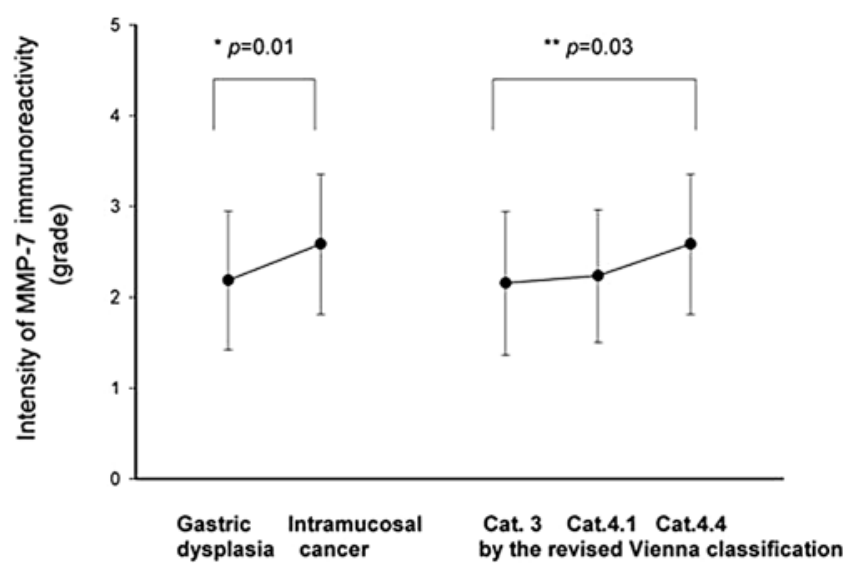

Fig. 4. Intensity of MMP-7 immunoreactivity: the sample tissues were classified into the categories of gastric dysplasia and intramucosal cancer (left) and subgrouped by the revised Vienna classification (right). The results are expressed as means \pm standard error. Single and double asterisks denote $P$ $<0.05$ (Student's $t$-test and one-way analysis of variance (ANOVA). Cat., Category

Table 2. Prevalence of $c a g$ PAI (cagA and $\operatorname{cagL}$ ) in gastric epithelial neoplasias

\begin{tabular}{lccl}
\hline & $\begin{array}{c}\text { Gastric dysplasia; } \\
n=76(\%)\end{array}$ & $\begin{array}{c}\text { Intramucosal cancer; } \\
n=36(\%)\end{array}$ & $P$ \\
\hline Helicobacter pylori & $37(48.7)$ & $25(69.4)$ & 0.04 \\
Sex (M:F) & $20: 17$ & $14: 11$ & 0.17 \\
Age (years) & $63.24 \pm 7.95$ & $61.92 \pm 11.15$ & 0.60 \\
cagA & $20(54.1)$ & $22(88.0)$ & 0.005 \\
cagL & $15(40.5)$ & $11(44.0)$ & 0.50 \\
cagA and cagL & $11(29.7)$ & $10(40.0)$ & 0.48 \\
cagA or cagL & $23(62.2)$ & $23(92.0)$ & 0.008 \\
\hline
\end{tabular}

PAI, pathogenicity island 


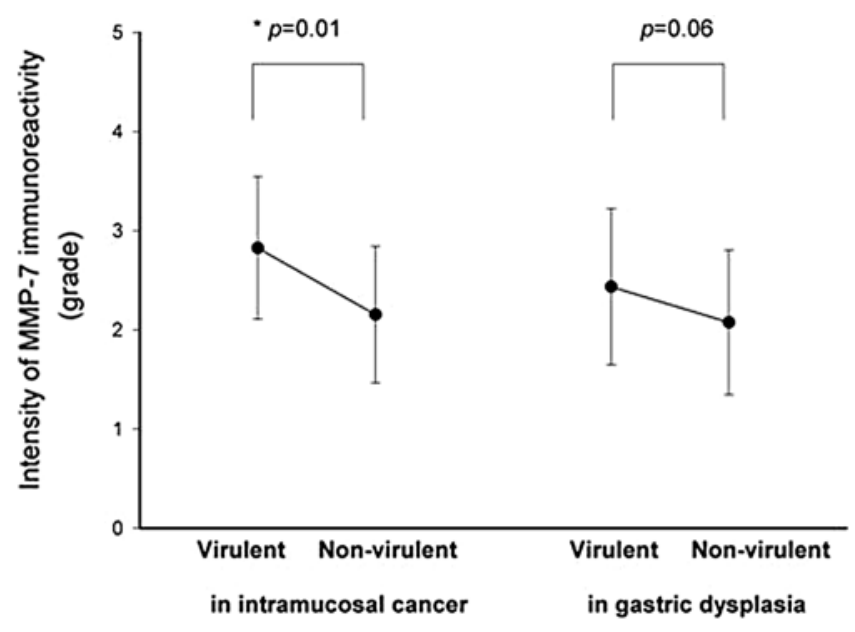

Fig. 5. Comparison of intensity of MMP-7 immunoreactivity in patients with intramucosal cancer (left) and those with gastric epithelial dysplasia (right) (infected with virulent or nonvirulent $H$. pylori strains). The results are expressed as means \pm standard error. Asterisk denotes $P<0.05$ (Student's $t$-test)

MMP-7 immunoreactivity than $H$. pylori-negative lesions $(2.80 \pm 1.04$ vs $2.09 \pm 0.70 ; P=0.04)$. When the intramucosal cancer lesions infected with virulent $H$. pylori strains (cagA- or cagL-positive) were compared to intramucosal cancer lesions without infection by these strains, the lesions infected with virulent $H$. pylori strains were noted to have a significant response to MMP-7 (2.80 \pm 1.04 vs $2.09 \pm 0.69 ; P=0.01)$. In gastric epithelial dysplasia, the lesions infected with virulent $H$. pylori strains had more intense staining than the lesions without infection by these strains, but no significant differences were observed $(2.43 \pm 0.79$ vs $2.08 \pm 0.73$; $P=0.06$; Fig. 5).

\section{Discussion}

Epidemiologically, H. pylori is now recognized as the major cause of gastric cancer $[18,19]$. In a subgroup with gastric atrophy and intestinal metaplasia, the eradication of $H$. pylori has been associated with the prevention or regression of these lesions, and the induction of apoptosis; in addition, $H$. pylori eradication has been shown to inhibit proliferation in $H$. pylori-infected gastric mucosa in animal models [20-23]. However, the effect of $H$. pylori eradication on premalignant lesions such as dysplasia and intramucosal cancer has not been determined. The effect of $H$. pylori treatment on the prevention of gastric cancer development remains controversial $[24,25]$. In the present study, we investigated the pathogenic role of virulent strains of $H$. pylori during the early stage of gastric carcinogenesis. The results showed that the frequency of cagA-positive $H$. pylori was greater in intramucosal cancers than in gastric epithelial dysplasias, although a selection bias of sample tissues could not be completely ruled out.

Gastric inflammation, atrophy, and intestinal metaplasia are already considered risk factors for gastric carcinogenesis [26]. Herein we showed that acute inflammation around intramucosal cancer was more intense than that around gastric dysplasia. The association between chronic inflammation and cancer is now well established, and $H$. pylori could be responsible for the chronic inflammation observed in gastric cancer [27]. We thought that bacterial virulence factors were more prevalent in intramucosal cancer than in gastric dysplasia and that they contributed to the more intense infiltration of PMN cells; this infiltration could play a role in the breakdown of the local epithelial barrier and the ongoing inflammation that progresses to gastric cancer. However, the results showing PMN infiltration had a great limitation, as there was no control group and no control biopsy specimens.

When all the sample tissues in the present study were subgrouped according to the revised Vienna classification, the frequency of cagA-positive H. pylori was shown to be significantly greater in cases with high-grade dysplasia (category 4.1) and intramucosal cancer (category 4.4) than in the other categories, illustrating disease progression. We did not include samples with noninvasive carcinoma (category 4.2) or samples suspicious of invasive carcinoma (category 4.3), because the use of these terms could be confusing in diagnosis according to whether a pathologist uses Western or Japanese nomenclature. In the West, noninvasive high-grade neoplasia is usually regarded as dysplasia that has not yet achieved invasion. In Japan, the same term means carcinoma in situ or superficial carcinoma that has already acquired the potential to invade, even if the potential is not currently realized. To make our results clear, we chose the definite terms "dysplasia" and "intramucosal carcinoma" for the lesions when two pathologists agreed on the diagnosis.

Although in the past many attempts have been made to understand and find a causal link between virulent H. pylori infection and specific gastrointestinal disease, data have been conflicting due to differences in study populations and designs. Especially in East Asia, several reports have not confirmed an association between cagA and disease, suggesting that the cagA gene is not a suitable marker for cag PAI-associated virulence [2830]. In another report, the presence of an intact cag PAI was correlated with the development of more severe pathology, and a partial deletion of cag appeared to render the organism less pathogenic [31]. These findings suggest that the presence of the cagA gene does not always signify that the presence of an intact cag PAI or other distinct cagA gene fragment - close to the pro- 
moter region or the cagA gene itself - is particularly associated with gastric pathology. In the present study, we selected primers for the cagA gene that were very close to the promoter region and were previously described by Ikenoue [32], who reported that the promoter region of the $\operatorname{cagA}$ gene, not the $\operatorname{cagA}$ gene itself, might be a better marker for cag PAI-associated virulence. Also, we detected the $\operatorname{cag} \mathrm{L}$ gene in neoplasia and paired normal specimens and we attempted to examine the pure intact state of cag PAI.

The extracellular matrix provides a structural framework for the support of cells and helps maintain cellular function. Cellular growth, migration, and degradation are dependent on the remodeling of the extracellular matrix, which is controlled by proteolytic enzymes called matrix metalloproteinases (MMPs) [33-35]. Especially, MMP-7, or matrilysin, is a secreted protease expressed by glandular and mucosal epithelial cells, keratinocytes, fibroblasts, and macrophages. It is expressed by tumor cells themselves and can be characterized in a tumorassociated fashion. At the gene level, nuclear $\beta$-catenin enhances the expression of the $M M P-7$ gene by binding with the T-cell factor/lymphoid enhancer factor family of transcription factors [36, 37]. As a consequence, this enzyme plays a significant role in the development of tumors. In previous reports, MMP-7 was upregulated in $H$. pylori gastritis, and this was the first stage in the progression to gastric carcinoma [14,15]. Elevated levels of MMP-7 have been detected in malignant lesions of the stomach [13, 37-41]. In both in vitro studies and in healthy subjects, the increased expression of MMP-7 induced in an $H$. pylori cag PAI-dependent manner was suggested to contribute to gastric carcinogenesis [14,42]. The goal of the present study was to determine whether cag status might alter the expression of MMP-7 in premalignant or early cancerous lesions.

We examined the expression of MMP-7 immunohistochemically and focused on the intensity and localization of MMP-7 in gastric epithelial dysplasia and intramucosal cancer samples, to determine the presence of cag PAI. Our results showed that intramucosal cancer had more intense MMP-7 immunoreactivity than gastric epithelial dysplasia. When we evaluated the relationship of $H$. pylori status and MMP immunoreactivity, a stronger response to MMP was noted in H. pylori-positive intramucosal cancer than in $H$. pylori-negative intramucosal cancer. Moreover, when the lesions infected with virulent $H$. pylori strains were compared with the lesions not infected with these strains, the intramucosal cancers had a more intense response. As these results suggest, $H$. pylori-associated or cag PAI-dependent MMP-7 upregulation could play an important role in the early changes in gastric carcinogenesis.

The expression of MMP-7 induced by virulent $H$. pylori strains has been identified in surface epithelial cells where there was dispersed staining of the cytoplasm that tended to be subnuclear on the basolateral side of the cells [43]. Our results revealed that the nuclear/subnuclear condensation of MMP-7 immunoreactivity in the intramucosal cancers was greater than that in the gastric dysplasia samples. Just prior to the invasive stage of epithelial tumors, basolateral staining (nuclear/subnuclear condensation) of MMP-7 has been observed, suggesting a direct role of MMP-7 as a matrixdegrading protease. This may be correlated with the activity of MMP-7 when it is released at either the apical or basolateral compartment. MMP-7 acts on various bioactive substrates - tumor necrosis factor- $\alpha$, Fas ligand, heparin-binding epidermal growth factor, Ecadherin, and $\beta 4$-integrin; in addition, the expression of MMP-7 is upregulated with tumor formation and progression [44-46].

In conclusion, infection with a virulent $H$. pylori strain is associated with early-stage gastric carcinogenesis that is associated with cag PAI-dependent MMP-7 upregulation. Large prospective studies are needed to further analyze the risk factors for gastric carcinogenesis and to clarify whether $H$. pylori eradication therapy is capable of preventing gastric carcinoma.

Acknowledgments This work was supported by a research grant from the St. Vincent Hospital, College of Medicine, the Catholic University of Korea.

\section{References}

1. Blaser MJ, Atherton JC. Helicobacter pylori persistence: biology and disease. J Clin Invest 2004;113:321-3.

2. Proença Módena JL, Lopes Sales AI, Olszanski Acrani G, Russo R, Vilela Ribeiro MA, Fukuhara Y, et al. Association between Helicobacter pylori genotypes and gastric disorders in relation to the cag pathogenicity island. Diagn Microbiol Infect Dis 2007;59:7-16.

3. Kuipers EJ, Perez-Perez GI, Meuwissen SG, Blaser MJ. Helicobacter pylori and atrophic gastritis: importance of the cagA status. J Natl Cancer Inst 1995;87:1777-80.

4. Crabtree JE, Farmery SM, Lindley IJ, Figura N, Peichl P, Tompkins DS. CagA/cytotoxic strains of Helicobacter pylori and interleukin-8 in gastric epithelial cell lines. J Clin Pathol 1994; 47:945-50.

5. Sharma SA, Tummuru MK, Miller GG, Blaser MJ. Interleukin-8 response of gastric epithelial cell lines to Helicobacter pylori stimulation in vitro. Infect Immun 1995;63:1681-7.

6. Peek RM Jr, Miller GG, Tham KT, Perez-Perez GI, Zhao X, Atherton JC, et al. Heightened inflammatory response and cytokine expression in vivo to cagA+Helicobacter pylori strains. Lab Invest 1995;73:760-70.

7. Blaser MJ, Perez-Perez GI, Kleanthous H, Cover TL, Peek RM, Chyou $\mathrm{PH}$, et al. Infection with Helicobacter pylori strains possessing cag $\mathrm{A}$ is associated with an increased risk of developing adenocarcinoma of the stomach. Cancer Res 1995;55:2111-5.

8. Rudi J, Kolb C, Maiwald M, Zuna I, von Herbay A, Galle PR, et al. Serum antibodies against Helicobacter pylori proteins VacA and CagA are associated with increased risk for gastric adenocarcinoma. Dig Dis Sci 1997;42:1652-9. 
9. Parsonnet J, Friedman GD, Orentreich N, Vogelman H. Risk for gastric cancer in people with CagA positive or CagA negative Helicobacter pylori infection. Gut 1997;40:297-301.

10. Kwok T, Zabler D, Urman S, Rohde M, Hartig R, Wessler S, et al. Helicobacter exploits integrin for type IV secretion and kinase activation. Nature 2007;449:798-9.

11. Parsons SL, Watson S, Brown P, Collins H, Steele RJC. Matrix metalloproteinases. Br J Surg 1997;84:160-6.

12. Sier CF, Hawinkels LJ, Zijlmans HJ, Zuidwijk K, de Jonge-Muller ES, Ferreira V, et al. Endothelium specific matrilysin (MMP-7) expression in human cancers. Matrix Biol 2008;27:267-71.

13. Kitoh T, Yanai H, Saitoh Y, Nakamura Y, Matsubara Y, Kitoh H, et al. Increased expression of matrix metalloproteinase-7 in invasive early gastric cancer. J Gastroenterol 2004;39:434-40.

14. Crawford HC, Krishna US, Israel DA, Matrisian LM, Washington MK, Peek RM Jr. Helicobacter pylori strain-selective induction of matrix metalloproteinase-7 in vitro and within gastric mucosa. Gastroenterology 2003;125:1125-36.

15. Bebb JR, Letley DP, Thomas RJ, Aviles F, Collins HM, Watson SA, et al. Helicobacter pylori upregulates matrilysin (MMP-7) in epithelial cells in vivo and in vitro in a Cag dependent manner. Gut 2003;52:1408-13.

16. Stolte M. The new Vienna classification of epithelial neoplasia of the gastrointestinal tract: advantages and disadvantages. Virchows Arch 2003;442:99-106.

17. Dixon MF, Genta RM, Yardley JH, Correa P. Classification and grading of gastritis. The updated Sydney system. International Workshop on the Histopathology of Gastritis, Houston 1994. Am J Surg Pathol 1996;20:1161-81.

18. Uemura N, Okamoto S, Yamamoto S, Matsumura N, Yamaguchi S, Yamakido M, et al. Helicobacter pylori infection and the development of gastric cancer. N Engl J Med 2001;345:784-9.

19. Peek RM Jr, Crabtree JE. Helicobacter pylori and gastric neoplasia. J Pathol $2006 ; 208: 233-48$.

20. Cai X, Carlson J, Stoicov C, Li H, Wang TC, Houghton J. Helicobacter felis eradication restores normal architecture and inhibits gastric cancer progression in $\mathrm{C} 57 \mathrm{Bl} / 6$ mice. Gastroenterology 2005;128:1937-52.

21. Cao X, Tsukamoto T, Nozaki K, Shimizu N, Mizoshita T, Kumagai $\mathrm{T}$, et al. Eradication of Helicobacter pylori induces apoptosis and inhibits proliferation of heterotopic proliferative glands in infected Mongolian gerbils. Cancer Sci 2004;95:872-7.

22. Leung WK, Lin SR, Ching JY, To KF, Ng EK, Chan FK, et al. Factors predicting progression of gastric intestinal metaplasia: results of a randomised trial on Helicobacter pylori eradication. Gut 2004;53:1244-9.

23. Sung JJ, Lin SR, Ching JY, Zhou LY, To KF, Wang RT, et al. Atrophy and intestinal metaplasia 1 year after cure of $H$. pylori infection: a prospective, randomized study. Gastroenterology 2000;119:7-14.

24. Lee YC, Lin JT, Chen TH, Wu MS. Is eradication of Helicobacter pylori the feasible way to prevent gastric cancer? New evidence and progress, but still a long way to go. J Formos Med Assoc 2008;107:591-9.

25. Wong BC, Lam SK, Wong WM, Chen JS, Zheng TT, Feng RE, et al. China Gastric Cancer Study Group: Helicobacter pylori eradication to prevent gastric cancer in a high-risk region of China: a randomized controlled trial. JAMA 2004;291:187-94.

26. Correa P. Helicobacter pylori and gastric carcinogenesis. Am J Surg Pathol 1995;19(Suppl 1):S37-S43.

27. Coussens LM, Werb Z. Inflammation and cancer. Nature 2002;420: $860-7$.

28. Sheu SM, Sheu BS, Yang HB, Li C, Chu TC, Wu JJ. Presence of ice A1 but not cagA, cagC, cagE, cagF, cagN, cagT, or orf13 genes of Helicobacter pylori is associated with more severe gastric inflammation in Taiwanese. J Formos Med Assoc 2002;101: $18-23$.

29. Valmaseda Pérez T, Gisbert JP, Pajares García JM. Geographic differences and the role of cagA gene in gastroduodenal diseases associated with Helicobacter pylori infection. Rev Esp Enferm Dig 2001;93:471-80.

30. Mattar R, dos Santos AF, Eisig JN, Rodrigues TN, Silva FM, Lupinacci RM, et al. No correlation of babA2 with vacA and cagA genotypes of Helicobacter pylori and grading of gastritis from peptic ulcer disease patients in Brazil. Helicobacter 2005;10: 601-8.

31. Ali M, Khan AA, Tiwari SK, Ahmed N, Rao LV, Habibullah CM. Association between cag-pathogenicity island in Helicobacter pylori isolates from peptic ulcer, gastric carcinoma, and non-ulcer dyspepsia subjects with histological changes. World J Gastroenterol 2005;11:6815-22.

32. Ikenoue T, Maeda S, Ogura K, Akanuma M, Mitsuno Y, Imai Y, et al. Determination of Helicobacter pylori virulence by simple gene analysis of the cag pathogenicity island. Clin Diagn Lab Immunol 2001;8:181-6.

33. Clark IM, Swingler TE, Sampieri CL, Edwards DR. The regulation of matrix metalloproteinases and their inhibitors. Int $\mathrm{J}$ Biochem Cell Biol 2008;40:1362-78.

34. Nelson AR, Fingleton B, Rothenberg ML, Matrisian LM. Matrix metalloproteinases: biologic activity and clinical implications. J Clin Oncol 2000;18:1135-49.

35. Ii M, Yamamoto H, Adachi Y, Maruyama Y, Shinomura Y. Role of matrix metalloproteinase-7 (matrilysin) in human cancer invasion, apoptosis, growth, and angiogenesis. Exp Biol Med 2006; 231:20-7.

36. Matono $\mathrm{H}$, Oda $\mathrm{Y}$, Nakamori $\mathrm{M}$, Tamiya $\mathrm{S}$, Yamamoto $\mathrm{H}$, Yokoyama R, et al. Correlation between beta-catenin widespread nuclear expression and matrix metalloproteinase-7 overexpression in sporadic desmoid tumors. Hum Pathol 2008;39:1802-8.

37. Aihara R, Mochiki E, Nakabayashi T, Akazawa K, Asao T, Kuwano H. Clinical significance of mucin phenotype, beta-catenin and matrix metalloproteinase 7 in early undifferentiated gastric carcinoma. Br J Surg 2005;92:454-62.

38. McDonnell S, Navre M, Coffey RJ Jr, Matrisian LM. Expression and localization of the matrix metalloproteinase pump-1 (MMP-7) in human gastric and colon carcinomas. Mol Carcinog 1991;4: 527-33.

39. Yamashita K, Azumano I, Mai M, Okada Y. Expression and tissue localization of matrix metalloproteinase 7 (matrilysin) in human gastric carcinomas. Implications for vessel invasion and metastasis. Int J Cancer 1998;79:187-94.

40. Honda M, Mori M, Ueo H, Sugimachi K, Akiyoshi T. Matrix metalloproteinase-7 expression in gastric carcinoma. Gut 1996;39: 444-8.

41. Adachi Y, Itoh F, Yamamoto H, Matsuno K, Arimura Y, Kusano $\mathrm{M}$, et al. Matrix metalloproteinase matrilysin (MMP-7) participates in the progression of human gastric and esophageal cancers. Int J Oncol 1998;13:1031-5.

42. Ogden SR, Wroblewski LE, Weydig C, Romero-Gallo J, O'Brien DP, Israel DA, et al. p120 and Kaiso regulate Helicobacter pyloriinduced expression of matrix metalloproteinase-7. Mol Biol Cell 2008;19:4110-21.

43. Wroblewski LE, Noble PJ, Pagliocca A, Pritchard DM, Hart CA, Campbell F, et al. Stimulation of MMP-7 (matrilysin) by Helicobacter pylori in human gastric epithelial cells: role in epithelial cell migration. J Cell Sci 2003 15;116:3017-26.

44. McCaig C, Duval C, Hemers E, Steele I, Pritchard DM, Przemeck $\mathrm{S}$, et al. The role of matrix metalloproteinase-7 in redefining the gastric microenvironment in response to Helicobacter pylori. Gastroenterology 2006;130:1754-63.

45. Lee KH, Choi EY, Hyun MS, Jang BI, Kim TN, Kim SW, et al. Association of extracellular cleavage of E-cadherin mediated by MMP-7 with HGF-induced in vitro invasion in human stomach cancer cells. Eur Surg Res 2007;39:208-15.

46. Aihara R, Mochiki E, Kamiyama Y, Ohno T, Asao T, Kuwano H. Matrilysin expression is a useful marker of submucosal invasion and lymph node metastasis in early stage signet ring cell carcinoma of the stomach. J Surg Oncol 2006;93:491-7. 